\title{
Radio Listenership Among the Elite in Cape Coast Metropolis
}

\author{
Moses Segbenya* \\ College of Distance Education, University of Cape Coast, Cape Coast, Ghana \\ Antwi-Konadu, Kwabena \\ ATL Radio, University of Cape Coast, Cape Coast, Ghana \\ Peniana, Fred \\ Department of Mathematics and ICT, University of Cape Coast, Cape Coast, Ghana \\ Adu-Poku, Felix \\ Division of Corporate Affairs, University of Cape Coast, Cape Coast, Ghana
}

\begin{abstract}
The paper investigated into the radio listenership among the elite in Cape Coast Metropolis (CCM). The study employed the descriptive cross-sectional survey design. The population of the study comprised 379 elite from the public and the private sectors. Stratified and simple random sampling techniques were employed to select respondents from the various strata and to administer self administered survey questionnaire. Quantitative data collected was analysed with descriptive statistics and inferential statistics such as frequencies, percentages, means, standard deviations, and one - way analysis. The study found that majority of elite listeners of radio in CCM were 20-25 years, males, government employees and first-degree holders. The best three radio stations in CCM were Atlantic Fm, Cape FM, and Eagle FM. The major programme of interest to listeners of radio in CCM was the morning show. Respondents in CCM listened to the radio more in the morning and evening (before work and after work) as compared to during working hours. The level of satisfaction for radio in CCM by respondents was very good; however, they also listened to other radio stations outside CCM largely from Accra, for which respondents' level of satisfaction was rather excellent. It was therefore recommended that management of radio stations in CCM continue to partner with radio stations in Accra for broadcasting their major news; and introduce new and interesting programmes to capture and retain listeners during working hours and for listeners within the age bracket of 41 and above.
\end{abstract}

Keywords: Radio, Listenership, Elite, Metropolis, Programmes and Factors

DOI: $10.7176 / \mathrm{NMMC} / 94-03$

Publication date: December $31^{\text {st }} 2020$

\section{Introduction}

1.1 Background to the Study

Radio broadcasting plays several important roles in peoples' lives all over world and is used as major sources of information and news on what is happening within the local community, at the national level or at the international level (Anquandah, 2012, Gathigi, 2009). According to Kwakwa (2012) radio is seen as a companion by providing different forms of entertainment and a discursive space about different issues that affect individuals and group or community. Scanell (1996) earlier opined that radio offers a medium for different voices to be heard. Radio provides an opportunity for people to interpret the world on their own (Hendy, 2000). For these reason Gathigi, (2009) revealed that radio remains a simple medium and the less expensive as compared to other media. He further concluded that radio has the emancipation power and allows people who are otherwise excluded from other forms of mainstream media such as print media, a channel to express their voice and a role to play in public discourse. Radio broadcasting provides social, political, economic, and cultural information access and participation of different population groupings.

Thus radio enables individuals and groups to fulfill a basic human right to information suggested by the United Nations (UN, 1961). This is because people used the information to make informed decisions, to increase their knowledge, and to get direction to essential services. Thus, radio is an instrument for causing social change through information. Radio has proved to be an effective medium for social change programming and has been used to address issues related to education, health, population, economic empowerment, peace-building, environment, and human rights, in Africa, Asia, and Latin America (Melkote \& Steves, 2002). However, Wilson (2000) disclosed that there are wide access disparities between urban and rural populations in Africa. Alumuku (2006) also revealed that the use of community radio in Africa is a conduit for the participation of the local population to address specific interests.

According to Anquandah (2012), radio was introduced to Ghana (hitherto Gold Coast) by Governor Sir Arnold Hodson in 1935 in his maiden broadcast on the new broadcast service; Station ZOY was received by some 
300 subscribers in Accra who used diffusion boxes. The station was established as a public service tool that brought news, entertainment, and music into the homes of its initial subscribers in Accra (Annor-Antwi, 2009). However, the station was used for different purposes from 1939 to include the spread of British propaganda during World War II. The station was established as a department on its own in 1953 and was renamed the Ghana Broadcasting Corporation (GBC) to serve as the mouthpiece of the government (Ofori-Boateng, 1997).

In order to make radio and it benefits available to other nationals in the other parts of Ghana during the colonial epoch, subsidiary stations were established in district centres of the colonial and postcolonial administrations in Cape Coast, Kumasi, Koforidua, and Sekondi. These stations were equipped to spread out radio broadcasting from Accra to the other parts of the country. Anquandah (2012) revealed that radio in Ghana remained a state monopoly until 1995 when the University of Ghana's Voice of Legon (later renamed; Radio Universe) was established. Anquandah, therefore, argued that the Voice of Legon became the first non-governmental radio station in Ghana. The passage of the NCA Act 524 by the Parliament of Ghana in 1996, which established the National Communications Authority, establishes the authority to regulate communications by wire, cable, radio, television, satellite and similar means of technology for the orderly development and operation of efficient communications services in Ghana (www.nca.org.gh, 2016; Anquandah, 2012). The National Communications Authority's (NCA) 2016 report revealed that 452 radio stations had been authorised to operate in Ghana, out of which 354 were operational as at the third quarter of 2016

The proliferation of the Ghanaian media scene accompanied by programmes variety of radio stations afford individual listeners the opportunity and the options to choose which station to listen at any point in time (Boateng, 2009). Radio stations in Ghana provide varieties of programmes or activities, including talk shows, music, drama, news, announcements, and education, which provide useful information to the listeners in Ghana. National Communication Authority (2016) revealed that there are about 46 and 52 radio stations in Ashanti and Brong Ahafo regions respectively; 35 and 47 radio stations in Eastern and Greater Accra region respectively; 30, 12 and 11 radio stations in Northern, Upper East And Upper west respectively; as well as 36 and 56 in the Volta and the Western regions in Ghana providing variety of programmes.

The Central Region, which hosts Cape Coast Municipality, the study area, was the former administrative centre of the Gold Coast. Its capital, Cape Coast, with the local name Oguaa was the capital of the Gold Coast until 1877 when the capital was moved to Accra. The Central Region shares common boundaries with Western Region on the west, Ashanti and Eastern Regions on the North, and Greater Accra Region on the East. In terms of industrial employment in the region according to Ghana Statistics Service (2013), the region (Central Region) employed people in about 19 industries such as 4.7 percent in educational sector; $42.6 \%$ in agriculture; 17.3 percent in the wholesale and retail, repair of motor vehicles and motorcycles industry, and 11.6 percent were also employed in the manufacturing sector among others. In 2010 the population of Central Region was 2,201,863, accounting for about 8.9 percent of the population of Ghana with an annual growth rate of 3.1 percent between 2000 and 2010 . It occupies an area 4.1 percent of Ghana's land area, making it the third smallest in area after Greater Accra and Upper East (Ghana Statistical Service, 2013).

Central Region hosts about 29 radio stations that serve the interest of both the urban and the rural communities in the region. Cape Coast Metropolis (CCM), the study area alone host about 10 radio stations out of the 29 radio stations in the region. However, residents in the CCM and the Central Region are able to access almost all the radio stations in the Greater Accra region, Ashanti Region, and Western Region among others (Borman, 2015). Radio stations in the metropolis and the Central Region have to compete for listenership with other radio stations mostly from Greater Accra among others. Advancement in technology has led to the compression of frequencies to digital formats that can be accessed via mobile phones, mp3 players, iPods, iPads, satellite decoders and the internet. To this end, people within the CCM catchment area can receive any other station's signal from any other parts of the country provided they have access to such technological devices that receive signals from their desired radio stations (Ocran, 2015). Radio listeners in the CCM can be broadly divided into two such as literate and illiterate listening population and programmes of radio station are either largely English programmes or vanacular programmes. However this study focuses on only the literate population.

From the forgoing discussion one wonders which radio station do the people in CCM listen to since they are confronted with competing radio stations in the Central Region and others from Greater Accra Region, Ashanti Region and Western Region. What programme/s would make/s a radio station a favourite for listeners among others? For this reason, this study sought to answer the following research questions.

1. What category of elites listen to radio in Cape Coast Metropolis?

2. How do demographic variables of respondents affect the predetermined factors on their choice of radio in CCM?

3. What programmes and timing make the best radio station in the CCM to respondents and why would respondents choose a radio station outside CCM? 


\section{Theoretical and conceptual discussion}

The study is anchored on the Uses and Gratifications theory of mass communication which postulates that media audiences and for that matter radio listeners have needs they seek to gratify as they interact with radio or the media. According to Bittner (1996) and Anquandah (2012) the uses of gratifications theory focuses on consumers' motivations and concerns for using various media rather than the message itself. In other words, broadcast audiences are largely responsible for choosing the media to meet specified needs they have. Meanwhile, an earlier publication by Katz, Gurevitch, and Haas (1973) indicated that studies concerning the uses of the gratifications approach are concerned with the social and psychological origins of needs. Later on, Chioma, Solo-Anaeto, Jegede (2015) further explained that these needs range from; self-awareness, surveillance, social integration, and entertainment needs, all of which result from the immediate psychological, social, and physical needs of the audience, which often varies.

According to Weiss in Anquandah (2012), the needs of the media audience could be categorised into informational-educational and fantasist-escapist entertainment. McQuail, Blumler and Brown (1972), earlier found that media audience needs could be put into four categories. Diversion: The first category relates to how individuals escape from their routine and problems to achieve emotional release. Personal relationships, the second category means using the media to substitute companionship. The third category, personal identity or individual psychology, deals with using the media for value reinforcement or reassurance, self-understanding, and reality exploration. Surveillance is the fourth category, which implies getting information on things that might affect one or that will help one do or accomplish something. For this reasons, Chioma, Solo-Anaeto, Jegede (2015) concluded that since media audiences are only interested in contents that will gratify their needs, it is, therefore, the responsibility of the media or radio stations to ensure that such messages exist; design their programming with gratifying specific needs of a targeted audience(s) in consideration. The use of uses and gratification theory is relevant to this study as it sought to find out what programme is of interest to respondents to make the best radio station in CCM or beyond the region.

In an attempt to serve and retain their listeners, radio stations usually host several radio programmes within the 24 hours of the day. GeoPoll (2015) revealed that radio listeners enjoy and patronize morning shows more than other programmes hosted by radio stations in Accra. Morning shows in Ghana normally comprised news, sports, health tit beat, newspaper review and discussion of topical political current issues of national interest. Other programs identified were drive time, hourly news, announcement, music and entertainment or drive time, political talk show, marriage and relationship programmes, community development programmes, health and religious programmes. Each of these programmes has been indicated to have varied effect on listeners. Radio audience thus also listens to different radio stations at different times for different reasons.

\section{Methodology}

This study adopted the quantitative approach from the positivist epistemology and ontological perspective. The research design employed was a descriptive cross-sectional survey design. The reason that necessitated this was that the study sought to collect one-time large data from more educated listeners of radio in CCM and describe what actually would be found in CCM regarding radio listenership. The population of the study comprised the elite from the public sector and the private sector. The subsectors forming both the public and private sectors of the study included water, information, communication, finance and insurance, security, health, education, and hotels and restaurants. The elite's total population in these subsectors comprised 20814 as at 2010 (Ghana Statistical Service, 2013) plus 2196, a 2 percent population growth from 2010 to 2015, making the total population stood at 23,310. Using Krejcian and Morgan's (1960) sample size determination table, a sample of 379 samples was drawn from the total population.

The stratified Probability sampling technique was adapted to draw 236 sample representing 62.4 percent and 143, representing 37.6 percent from the public and private sectors, respectively for the study. Additionally, a simple random sampling technique was also employed to administer research instrument to respondents. The research instrument used was a self-administered questionnaire. The questionnaire entails both open and closed-ended questions that were measured on a five-point scale of 1 to 5 , with 1 representing low agreement while 5 represented strong agreement. Since the study adopted the quantitative or positivist paradigm, all opened ended questions were coded and used quantitatively. The two sections of the instrument were Section A, which was on respondents' biodata, and Section B, which also captured issues on factors influencing radio and listenership choice in CCM. A Cronbach's alpha of .873 was obtained as a result for the pretest of the instrument, indicating that the instrument was good and could measure what it was intended to measure.

Data collection was done in 2016 with the supports of trained research assistants adhering to all ethical standards, including informed consent. In all, 255 questionnaires were returned, representing a 67.3 percent response rate. Descriptive statistics and inferential statistics such as frequencies, percentages, means, standard deviations, and one-way analysis of variance were used to analyse the data. The remaining section focuses on results and analysis, followed by recommendations for the management of radio stations in CCM. 


\section{Results and Analysis}

Presentation of the result under this section is based on the three research questions that guided the study. The three research questions were what caliber of people listens to radio in Cape Coast Metropolis in terms of gender, age, and employment status and level education?; How do demographic variables of respondents affect the predetermined factors on their choice of radio in CCM?; and lastly what programmes and timing make the best radio station in the CCM to respondents and why would respondents choose a radio station outside CCM?

4.1 Research Question One: What category of the elites listens to the radio in Cape Coast Metropolis? Research question one sought to determine the category of the elites that listen to the radio in Cape Coast Metropolis and this was examined in terms of gender, age, employment status and level of education. Descriptive statistics such as cross-tabulation, percentages, and frequencies were used to report responses regarding research question one. As seen from Table 1 is that most listeners of radio in CCM who were the respondents for this study were males $(74.3 \%)$ and were within $26-30$ age bracket. The majority of the female respondents, however, were within $20-$ 25 years. This means that males in Cape Coast have more interest and time listening to radio in the metropolis as compared to their female counterparts. That notwithstanding, younger women had more interest in listening to the radio as compared to older females. This could be as a result of a quest for information in terms of national happenings and time as well as a preference to listen to radio in Cape Coast Metropolis, which males and younger females seem to have done better. The findings agree with Ocran's (2015) findings that men search for information and are more interested in listening to radio than women. The results did not corroborate that of Bormann (2015), who found respondents above 31 to 40 years to be more interested in listening to the radio. Table 1: Demographic Characteristics of Respondents

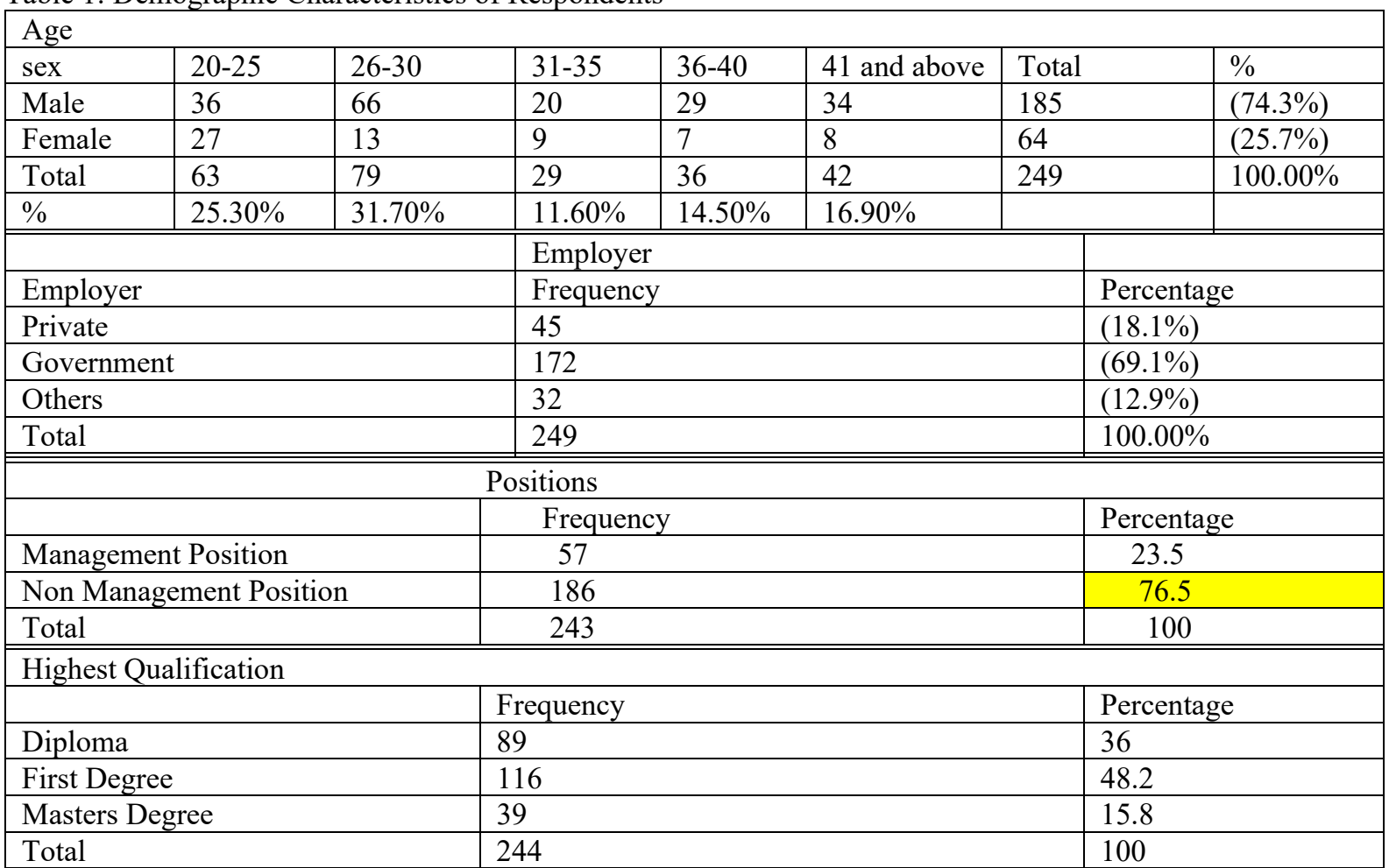

Page $/ 6$

Field Data, (2016)

In terms of respondents' employment status, it can be found in Table 1 that most of the respondents were government employees, with 69.1 percent. Additionally, there were more first degree holders $(48.2 \%)$ followed by diploma holders $(36.60 \%)$ in terms of respondents' highest educational level. The majority of the respondents were also in non-management positions $(76.5 \%)$. This means that out of the elite in CCM, more first degree holders and non-management employees, as well as government employees, listen to radio more than their other elite counterparts. This finding disagrees with that of Ocran (2015), who found that more master's degree holders listened more to radio as compared to first degree holders.

4.2 Research question two: How do respondents' demographic variables affect the predetermined factors on respondents' choice of radio in CCM?

The second research question that the study sought to answer was to assess how respondents perceive the effect of 
predetermined factors on their choice of radio station in CCM. These nine predetermined factors were identified in literature to have had varied level of effect on radio listeners' choice of radio. Three demographic variables used to answer this research question were age, educational level and employment status. The first part of the research question two which deals with how respondents' perceived the factors was answered with descriptive statistics such as mean and standard deviation and the results to that effect can be seen from Table 2

Table 2: Respondents level of importance attached to the effects of predetermine factors on their choice of radio in $\mathrm{CCM}$

\begin{tabular}{|l|l|l|l|l|l|l|}
\hline & $\mathrm{N}$ & Minimum & Maximum & Mean & Std. Deviation & \\
\hline News Coverage & 250 & 1 & 5 & 3.816 & 1.0091 & \\
\hline Type of Programme & 250 & 1 & 5 & 3.708 & 1.0711 & \\
\hline Station Presenters & 250 & 1 & 5 & 3.28 & 1.0421 & \\
\hline Station's Image & 250 & 1 & 5 & 3.064 & 1.2499 & \\
\hline Status as a Worker & 249 & 1 & 5 & 2.6988 & 1.2022 & \\
\hline Religious Belief & 250 & 1 & 5 & 2.648 & 1.2627 & \\
\hline Your Political & 250 & 1 & 5 & 2.588 & 1.3659 & \\
\hline Influence of Others & 251 & 1 & 5 & 2.53 & 1.122 & \\
\hline Type of Commercials Run & 250 & 1 & 5 & 2.524 & 1.1128 & \\
\hline
\end{tabular}

Page /7 Scale: $2.0-2.4=$ very low; 2.5-2.9=low; 3.0-3.4= high; 3.5-4=very high

Field Data, (2016)

From Table 2, it can be deduced that respondents perceived two factors such as news coverage $(\mathrm{M}=3.816$; $\mathrm{SD}=1.001)$ and type of programme run $(\mathrm{M}=3.708, \mathrm{SD}=1.0711)$ by a radio station to be very high. Additionally, station presenters $(M=3.28, S D=1.0421)$ and the station's image $(M=3.064, S D=1.2499)$ were perceived as high. All other factors such as status as a worker, religious belief, political orientation, influence of others, and type of commercial run were perceived to below. This result agrees with Anquandah's (2012) findings who found that respondents in New Abirem perceived news coverage and current affairs more positively than other factors.

To further consolidate the findings for research question two, the study determined the effect of age on respondents' appreciation of the predetermined factors and the results to this effect can be seen from Table 3. The results from the ANOVA analysis reported in Table 3 shows that respondents within the age bracket of 31- 35 perceived image, presenters, status as a worker, commercial run, and influence of others, higher than other age groups. News coverage and types of programmes were also perceived higher by respondents in the age bracket of 36-40, and finally, religious beliefs and political orientation were perceived higher by respondents in the age bracket of 41 and above. This means that all the respondents do not attach the same importance to all the predetermined factors as can be seen from the table. Political programmes favoured the adult listeners above 41 years whilst news, image and programmes also were favoured by respondents below 41 years. The finding corroborates that of Kwakwa (2012), who also found a similar outcome for respondents in the Eastern Region of Ghana.

Table 3. The Effect of Age on Factors Influencing Respondents' Choice of Radio Station in CCM

\begin{tabular}{|l|l|l|l|l|l|l|l|}
\hline & & & & Sig & $\eta^{2}$ \\
\hline \multirow{5}{*}{} & & $\mathrm{N}$ & Mean & Std. Deviation & & & \\
\hline & $20-25$ & 62 & 2.8548 & 1.26552 & 0.575 & 0.681 & 0.009 \\
\hline & $26-30$ & 78 & 3.1282 & 1.22059 & & & \\
\hline & $31-35$ & 29 & 3.1724 & 1.33815 & & & \\
\hline & $36-40$ & 37 & 3.0541 & 1.33221 & & & \\
\hline & 41 and above & 41 & 3.1463 & 1.19501 & & & \\
\hline & Total & 247 & 3.0567 & 1.2546 & & & \\
\hline \multirow{5}{*}{ Station's Image } & $20-25$ & 62 & 3.6774 & 1.02067 & 5.744 & 0.000 & 0.087 \\
\hline & $26-30$ & 78 & 3.6923 & 1.01044 & & & \\
\hline & $31-35$ & 29 & 3.5862 & 1.23974 & & & \\
\hline & $36-40$ & 37 & 4.5135 & 0.69208 & & & \\
\hline & 41 and above & 41 & 3.8049 & 0.84319 & & & \\
\hline & Total & 247 & 3.8178 & 1.01373 & & & \\
\hline \multirow{5}{*}{ News Coverage } & $20-25$ & 62 & 3.7419 & 1.10045 & 1.883 & 0.114 & 0.030 \\
\hline & $26-30$ & 78 & 3.6154 & 1.07184 & & & \\
\hline & $31-35$ & 29 & 3.5517 & 1.1828 & & & \\
\hline & $36-40$ & 37 & 4.1351 & 1.00449 & & & \\
\hline & 41 and above & 41 & 3.6098 & 0.97155 & & & \\
\hline
\end{tabular}




\begin{tabular}{|c|c|c|c|c|c|c|c|}
\hline & & $\mathrm{N}$ & Mean & Std. Deviation & $\mathrm{F}$ & Sig & $\eta^{2}$ \\
\hline \multirow[b]{6}{*}{ Station Presentors } & $20-25$ & 62 & 3.1774 & 0.85936 & 1.093 & 0.361 & 0.018 \\
\hline & $26-30$ & 78 & 3.2051 & 1.03646 & & & \\
\hline & $31-35$ & 29 & 3.5517 & 1.08845 & & & \\
\hline & $36-40$ & 37 & 3.2162 & 1.3771 & & & \\
\hline & 41 and above & 41 & 3.4634 & 0.9246 & & & \\
\hline & Total & 247 & 3.2834 & 1.04407 & & & \\
\hline \multirow[b]{6}{*}{ Your Status As A Worker } & $20-25$ & 61 & 2.3607 & 1.04933 & 6.675 & 0.000 & 0.100 \\
\hline & $26-30$ & 78 & 2.4103 & 1.17811 & & & \\
\hline & $31-35$ & 29 & 3.3793 & 1.08278 & & & \\
\hline & $36-40$ & 37 & 3.1351 & 1.27284 & & & \\
\hline & 41 and above & 41 & 2.9024 & 1.2001 & & & \\
\hline & Total & 246 & 2.7033 & 1.20769 & & & \\
\hline \multirow[b]{6}{*}{ Commercials Run } & $20-25$ & 62 & 2.5161 & 1.06728 & 2.415 & 0.05 & 0.038 \\
\hline & $26-30$ & 78 & 2.5769 & 1.02589 & & & \\
\hline & $31-35$ & 29 & 2.8276 & 1.07135 & & & \\
\hline & $36-40$ & 37 & 2.0541 & 1.28983 & & & \\
\hline & 41 and above & 41 & 2.6585 & 1.15347 & & & \\
\hline & Total & 247 & 2.5263 & 1.11818 & & & \\
\hline \multirow[b]{6}{*}{ Influence Of Others Influences } & $20-25$ & 62 & 2.565 & 1.0958 & 2.03 & 0.091 & 0.032 \\
\hline & $26-30$ & 78 & 2.436 & 1.2124 & & & \\
\hline & $31-35$ & 29 & 2.828 & 1.2268 & & & \\
\hline & $36-40$ & 37 & 2.162 & 0.9864 & & & \\
\hline & 41 and above & 42 & 2.738 & 0.9892 & & & \\
\hline & Total & 248 & 2.524 & 1.1272 & & & \\
\hline \multirow[b]{6}{*}{ Religious Belief } & $20-25$ & 62 & 2.7903 & 1.16136 & 7.631 & 0.000 & 0.112 \\
\hline & $26-30$ & 78 & 2.2949 & 1.10617 & & & \\
\hline & $31-35$ & 29 & 3.069 & 1.33446 & & & \\
\hline & $36-40$ & 37 & 2.1081 & 1.28633 & & & \\
\hline & 41 and above & 41 & 3.2927 & 1.24988 & & & \\
\hline & Total & 247 & 2.6478 & 1.26291 & & & \\
\hline \multirow[b]{6}{*}{ Your Political Orientation } & $20-25$ & 62 & 2.5806 & 1.18111 & 4.493 & 0.002 & 0.069 \\
\hline & $26-30$ & 78 & 2.4615 & 1.50921 & & & \\
\hline & $31-35$ & 29 & 2.8966 & 1.44778 & & & \\
\hline & $36-40$ & 37 & 2 & 1.24722 & & & \\
\hline & 41 and above & 41 & 3.1951 & 1.16661 & & & \\
\hline & Total & 247 & 2.5951 & 1.3697 & & & \\
\hline
\end{tabular}

Page $/ 7$

Field Data, (2016)

There was a statistically significant difference at $\mathrm{p}<.05$ level in LOT scores for five out of the nine variables of the study such as news coverage $[\mathrm{F}(4,250)=5.744, \mathrm{p}=.000]$, the status of respondents $[\mathrm{F}(4,250)=6.675$, $\mathrm{p}=.000]$, commercial run $[\mathrm{F}(4,250)=2.415, \mathrm{p}=.05]$; Religious beliefs $[\mathrm{F}(4,250)=7.631, \mathrm{p}=.000]$ and political orientation $[\mathrm{F}(4,250)=4.493, \mathrm{p}=.002]$. This means that respondents rated the effects of station image, programmes, presenters, and influence of others to be insignificant in terms of their choice of radio in CCM.

The effect size, calculated using eta squared, was .087 for news coverage; 0.100 for status as worker; .038 for types of commercials run .112; for religious beliefs .069 ; for political orientation. This result means that the magnitude of effect was large for three factors such as news coverage, status as worker and religious beliefs; but moderate for political orientation and small for type of commercials rum. Post-hoc comparisons using the Tukey HSD test indicated that the mean score for respondents within $20-25$ age bracket $(\mathrm{M}=21.36, \mathrm{SD}=4.55)$ was significantly different from respondents in age brackets of 26- $30(\mathrm{M}=3.615, \mathrm{SD}=1.0718) ; 31-35(\mathrm{M}=3.5517, \mathrm{SD}=$ $1.1828)$ and $36-40(\mathrm{M}=4.135, \mathrm{SD}=1.0045)$ for the effect of news coverage on respondents choice of radio in CCM. The same scenarios of difference in terms of significance within age groups also occurred for the other four significant factors.

The effect of employment status on respondents' perception of how the factors of the study influenced their choice of a radio station in the CCM can be found in Table 4. Employment status was divided into three such as privately employed, government-employed, and others (unemployed). From the table, it can be deduced that there 
was no statistically significant difference between employment status and all the nine factors of study.

Table 4: the Effect of employment status on Factors for Respondents' Choice of Radio Station in CCM

\begin{tabular}{|c|c|c|c|c|c|c|}
\hline \multicolumn{2}{|l|}{ Employment status } & $\mathrm{N}$ & Mean & Std. Deviation & $\mathrm{F}$ & Sig. \\
\hline \multirow{4}{*}{ Station's Image } & Privately Employed & 43 & 3.0930 & 1.46082 & 1.408 & .247 \\
\hline & Government employed & 171 & 3.1228 & 1.24716 & & \\
\hline & Others & 33 & 2.7273 & .87581 & & \\
\hline & Total & 247 & 3.0648 & 1.24770 & & \\
\hline \multirow{4}{*}{ News Coverage } & Privately Employed & 43 & 3.7907 & .98942 & .172 & .842 \\
\hline & Government & 171 & 3.8363 & 1.01580 & & \\
\hline & Others & 33 & 3.7273 & 1.06867 & & \\
\hline & Total & 247 & 3.8138 & 1.01500 & & \\
\hline \multirow{4}{*}{ Type Of Programme } & Privately Employed & 43 & 3.5349 & 1.12014 & 1.538 & .217 \\
\hline & Government & 171 & 3.7076 & 1.07205 & & \\
\hline & Others & 33 & 3.9697 & 1.01504 & & \\
\hline & Total & 247 & 3.7126 & 1.07558 & 2.647 & .073 \\
\hline \multirow{4}{*}{ Station Presenters } & Privately Employed & 43 & 3.0233 & 1.10170 & & \\
\hline & Government & 171 & 3.3801 & 1.03552 & & \\
\hline & Others & 33 & 3.0909 & .97991 & & \\
\hline & Total & 247 & 3.2794 & 1.04711 & & \\
\hline \multirow{4}{*}{ Status As A Worker } & Privately Employed & 43 & 2.5349 & 1.14119 & 1.050 & .352 \\
\hline & Government & 170 & 2.7000 & 1.23005 & & \\
\hline & Others & 33 & 2.9394 & 1.17099 & & \\
\hline & Total & 246 & 2.7033 & 1.20769 & & \\
\hline \multirow{4}{*}{ Type Of Commercials Run } & Privately Employed & 43 & 2.4419 & 1.11915 & 1.378 & .254 \\
\hline & Government & 171 & 2.6023 & 1.10868 & & \\
\hline & Others & 33 & 2.2727 & 1.12563 & & \\
\hline & Total & 247 & 2.5304 & 1.11443 & & \\
\hline \multirow{4}{*}{ Influence Of Others } & Privately Employed & 44 & 2.614 & 1.2979 & 2.524 & .082 \\
\hline & Government & 171 & 2.585 & 1.1049 & & \\
\hline & Others & 33 & 2.121 & .9273 & & \\
\hline & Total & 248 & 2.528 & 1.1271 & & \\
\hline \multirow{4}{*}{ Religious Belief } & Privately Employed & 43 & 2.4884 & 1.36926 & 2.048 & .131 \\
\hline & Government & 171 & 2.7602 & 1.22994 & & \\
\hline & Others & 33 & 2.3333 & 1.26656 & & \\
\hline & Total & 247 & 2.6559 & 1.26515 & & \\
\hline \multirow{4}{*}{ Political Orientation } & Privately Employed & 43 & 2.4884 & 1.40360 & & \\
\hline & Government & 171 & 2.6842 & 1.36543 & 1.250 & .288 \\
\hline & Others & 33 & 2.3030 & 1.31065 & & \\
\hline & Total & 247 & 2.5992 & 1.36644 & & \\
\hline
\end{tabular}

Page /8

Field Data, (2016)

Table 5 shows results for the effect of educational level on how respondents perceived factors of the study. It can be said that there were statistically significant differences at $\mathrm{p}<.05$ level in LOT scores for the first five out of the nine variables of the study such as Station's Image $[\mathrm{F}(2,244)=7.018, \mathrm{p}=.001]$, news coverage $[\mathrm{F} 2,244)$ $=4.445, \mathrm{p}=.013]$, type of programmes $[\mathrm{F}(2,244)=5.673, \mathrm{p}=.004]$; station presenters $[\mathrm{F}(2,244)=3.163, \mathrm{p}=.044]$ and status as a worker $[\mathrm{F}(2,244)=3.11 \mathrm{p}=.046]$. The effect size, calculated using eta squared was however small since all values obtained for all the five significant factors fell below .06 and .14 threshold for moderate and high effect respectively. 
Table 5: The Effect of educational level on Factors Influencing Respondents' Choice of Radio Station in CCM

\begin{tabular}{|c|c|c|c|c|c|c|c|}
\hline & & $\mathrm{N}$ & Mean & Std. Deviation & $\mathrm{F}$ & Sig. & $\eta^{2}$ \\
\hline \multirow{4}{*}{ Station's Image } & Diploma & 87 & 2.7011 & 1.22108 & & & \\
\hline & First Degree & 118 & 3.2288 & 1.25685 & 7.018 & .001 & 0.05 \\
\hline & Masters Degree & 39 & 3.4615 & 1.07229 & & & \\
\hline & Total & 244 & 3.0779 & 1.24643 & & & \\
\hline \multirow{4}{*}{ News Coverage Influence } & Diploma & 87 & 3.5517 & 1.08648 & & & \\
\hline & First Degree & 118 & 3.9153 & .99207 & & & \\
\hline & Masters Degree & 39 & 4.0256 & .81069 & 4.445 & .013 & 0.04 \\
\hline & Total & 244 & 3.8033 & 1.01543 & & & \\
\hline \multirow{4}{*}{ Type Of Programme } & Diploma & 87 & 3.4138 & 1.17683 & & & \\
\hline & First Degree & 118 & 3.8475 & 1.02638 & & & \\
\hline & Masters Degree & 39 & 3.9744 & .81069 & 5.673 & .004 & 0.05 \\
\hline & Total & 244 & 3.7131 & 1.07328 & & & \\
\hline \multirow{4}{*}{ Station Presenters } & Diploma & 87 & 3.2069 & 1.18261 & & & \\
\hline & First Degree & 118 & 3.2119 & .91382 & & & \\
\hline & Masters Degree & 39 & 3.6667 & 1.05963 & 3.163 & .044 & 0.03 \\
\hline & Total & 244 & 3.2828 & 1.04918 & & & \\
\hline \multirow{4}{*}{ Status as a Worker } & Diploma & 87 & 2.6667 & 1.18779 & & & \\
\hline & First Degree & 117 & 2.6154 & 1.20949 & 3.11 & 0.46 & 0.03 \\
\hline & Masters Degree & 39 & 3.1538 & 1.15937 & & & \\
\hline & Total & 243 & 2.7202 & 1.20428 & & & \\
\hline \multirow{4}{*}{ Commercials Run } & Diploma & 87 & 2.4138 & .98302 & & & \\
\hline & First Degree & 118 & 2.5593 & 1.20215 & 1.224 & .296 & 0.01 \\
\hline & Masters Degree & 39 & 2.7436 & 1.11728 & & & \\
\hline & Total & 244 & 2.5369 & 1.11604 & & & \\
\hline \multirow{4}{*}{ Influence of Others } & Diploma & 88 & 2.557 & 1.1730 & & & \\
\hline & First Degree & 118 & 2.568 & 1.0898 & .211 & .810 & 0.001 \\
\hline & Masters Degree & 39 & 2.436 & 1.1424 & & & \\
\hline & Total & 245 & 2.543 & 1.1250 & & & \\
\hline \multirow{4}{*}{ Religious Belief } & Diploma & 87 & 2.7816 & 1.23350 & & & \\
\hline & First Degree & 118 & 2.6186 & 1.26707 & .636 & .530 & 0.005 \\
\hline & Masters Degree & 39 & 2.5385 & 1.37355 & & & \\
\hline & Total & 244 & 2.6639 & 1.27082 & & & \\
\hline \multirow{4}{*}{ Political Orientation } & Diploma & 87 & 2.8161 & 1.39375 & & & \\
\hline & First Degree & 118 & 2.5000 & 1.33173 & 1.715 & .182 & 0.014 \\
\hline & Masters Degree & 39 & 2.4359 & 1.33367 & & & \\
\hline & Total & 244 & 2.6025 & 1.35846 & & & \\
\hline
\end{tabular}

Page /8

Field Data, (2016)

4.3 Research questions three: What Programmes and Timing make the Best Radio Station in the CCM to Respondents?

The first part of research question three which borders on programmes of favourite radio in CCM was analysed with the use of cross-tabulation, frequencies and percentages and the results can be seen in Table 6. From the Table, it can be seen that the majority of the respondents (42\%) indicated that their number one radio station in the CCM was Atlantic Fm followed by Cape Fm (17.9\%) and Eagle Fm (15.6\%). The major programme of interest to listeners of radio in CCM was the morning show. The morning shows in the CCM entails morning news, newspaper review and panel discussion of topical political issues, among others. This result confirms the findings of GeoPoll (2015) that the most listened programmes among radio listeners in Accra was the morning show. In terms of programmes of interest for the most favourite radio in CCM, it can be confirmed that respondents selected more than one programme of interest for ATL fm followed by morning show, sports, drive time and news, among others. Additionally, programmes of interest for second and the third best radio stations in CCM according to respondents, were sports and news for Cape Fm; and morning show and music for Eagle Fm. 
Table 6: Respondents number one radio station programme in Cape Coast Metropolis

\begin{tabular}{|c|c|c|c|c|c|c|c|c|c|}
\hline & $\begin{array}{l}\text { Ocean } \\
\text { Drive }\end{array}$ & News & $\begin{array}{c}\text { Sport } \\
\mathrm{S} \\
\end{array}$ & $\begin{array}{c}\text { Mus } \\
\text { ic } \\
\end{array}$ & $\begin{array}{c}\text { Morning } \\
\text { Show }\end{array}$ & $\begin{array}{c}\text { Metro } \\
\text { Mix }\end{array}$ & $\begin{array}{c}\text { Political Talk } \\
\text { Show }\end{array}$ & $\begin{array}{c}\text { Multi } \\
\text { ple } \\
\text { Prog. }\end{array}$ & Total \\
\hline ATL fm & 12 & 11 & 12 & 2 & 19 & 1 & 6 & 26 & $\begin{array}{c}89 \\
(42 \%) \\
\end{array}$ \\
\hline Cape Fm & 10 & 7 & 9 & 4 & 3 & 1 & 0 & 4 & $\begin{array}{c}38 \\
(17.9)\end{array}$ \\
\hline Eagle Fm & 2 & 4 & 2 & 6 & 16 & 0 & 1 & 2 & $\begin{array}{c}33 \\
(15.6)\end{array}$ \\
\hline Live Fm & 2 & 2 & 3 & 2 & 0 & 0 & 0 & 1 & $\begin{array}{c}10 \\
(4.7 \%) \\
\end{array}$ \\
\hline $\begin{array}{l}\text { Radio } \\
\text { Central } \\
\end{array}$ & 2 & 5 & 4 & 2 & 1 & 0 & 0 & 1 & $\begin{array}{c}15 \\
(7.1 \%) \\
\end{array}$ \\
\hline Sompa Fm & 0 & 4 & 0 & 0 & 1 & 2 & 0 & 2 & $\begin{array}{c}9 \\
(4.2 \%) \\
\end{array}$ \\
\hline Yes Fm & 1 & 0 & 3 & 0 & 0 & 0 & 0 & 2 & $\begin{array}{c}6 \\
(2.8 \%) \\
\end{array}$ \\
\hline $\begin{array}{l}\text { Multiple } \\
\text { Choice }\end{array}$ & 0 & 5 & 5 & 1 & 0 & 0 & 0 & 1 & $\begin{array}{c}12 \\
(5.7 \%)\end{array}$ \\
\hline Total & 29 & 38 & 38 & 17 & 40 & 4 & 7 & 39 & 212 \\
\hline & $13.70 \%$ & $\begin{array}{c}17.90 \\
\%\end{array}$ & $\begin{array}{c}17.90 \\
\%\end{array}$ & $\begin{array}{c}8.00 \\
\%\end{array}$ & $18.90 \%$ & $1.90 \%$ & $3.30 \%$ & $\begin{array}{c}18.40 \\
\%\end{array}$ & $100 \%$ \\
\hline
\end{tabular}

The second aspect of research question three was on the timing for listening to the number one favourite radio in CCM and results to that effect is presented in Table 7. The responses are represented with frequencies and percentages. It is evident from Table 7 that majority of radio listeners in CCM do so before and after working hours. The results supports the earlier finding that majority of radio listeners in CCM rated morning shows higher than all other programmes of radio stations and also corroborates GeoPolls (2015) finding in Accra.

Table 7. Time of listening to number one radio station in the Cape Coast Metropolis

\begin{tabular}{|l|c|c|c|c|c|c|c|c|}
\hline & \multicolumn{2}{|c|}{$\begin{array}{c}\text { Before working hours } \\
\text { No. 1 Radio }\end{array}$} & \multicolumn{2}{c|}{$\begin{array}{c}\text { During } \\
\text { Total }\end{array}$} & \multicolumn{2}{c|}{$\begin{array}{c}\text { After working } \\
\text { hours }\end{array}$} & \multicolumn{2}{c|}{ Total } \\
\hline & No. & $\%$ & No. & $\%$ & No. & $\%$ & No. & $\%$ \\
\hline ATL Fm & 33 & 37.9 & 32 & 36.8 & 22 & 25.3 & 87 & 100 \\
\hline Cape Fm & 9 & 22.5 & 17 & 42.5 & 14 & 35 & 40 & 100 \\
\hline Eagle Fm & 14 & 46.7 & 8 & 26.7 & 8 & 26.7 & 30 & 100 \\
\hline Live Fm & 3 & 27.3 & 3 & 27.3 & 5 & 45.5 & 11 & 100 \\
\hline Radio Central & 4 & 30.8 & 6 & 46.2 & 3 & 23.1 & 13 & 100 \\
\hline Sompa Fm & 2 & 22.2 & 0 & 0 & 7 & 77.8 & 9 & 100 \\
\hline Yes Fm & 4 & 66.7 & 0 & 0 & 2 & 33.3 & 6 & 100 \\
\hline Multiple response & 5 & 38.5 & 1 & 7.69 & 7 & 53.8 & 13 & 100 \\
\hline Total & 74 & 35.4 & 67 & 32.1 & 68 & 32.5 & 209 & 100 \\
\hline$\%$ & 35.4067 & & 32.05742 & & 32.53589 & & 100 & \\
\hline
\end{tabular}

Page $/ 9$

Field Data, (2016)

Additionally, the individual radio station can also be reported that majority of respondents listen to Atlantic and Eagle Fm before working hours followed by during working hours; whilst the majority of listeners of Cape fm did so during working hours and after working hours. 
Table 8: Level of Satisfaction for Respondents 'Number One Radio Station in the Cape Coast Metropolis

\begin{tabular}{|l|c|c|c|c|c|}
\hline & Excellent & Very Good & Good & \multicolumn{2}{|c|}{ Total } \\
\hline & & & & No & $\%$ \\
\hline ATL Fm & 20 & 53 & 14 & 87 & 42 \\
\hline Cape Fm & 3 & 21 & 13 & 37 & 18 \\
\hline Eagle Fm & 9 & 13 & 7 & 29 & 14 \\
\hline Live Fm & 6 & 3 & 2 & 11 & 5.4 \\
\hline Radio Central & 3 & 5 & 5 & 13 & 6.3 \\
\hline Sompa Fm & 0 & 8 & 1 & 9 & 4.4 \\
\hline Yes Fm & 0 & 3 & 3 & 6 & 2.9 \\
\hline Others/Mutiple Choice & 4 & 7 & 2 & 13 & 6.3 \\
\hline TOTAL (No.) & 45 & 113 & 47 & 205 & 100 \\
\hline$\%$ & 21.95 & 55.1 & 22.93 & 100 & \\
\hline
\end{tabular}

Page $/ 9$

Field Data, (2016)

Table 8 also Highlighted respondents' satisfaction level with their number one radio station in the CCM. It can be seen that the satisfaction level for radio stations in CCM by the majority of the respondents was very good $(55.1 \%)$ and followed by good $(22.93 \%)$. The result shows that respondents' were not deriving the highest satisfaction (herein termed as excellent) from their number one radio stations in the CCM. For this purpose the study went ahead to find out from the respondents whether they listened to other radio stations outside the CCM. The results to this effect can be seen from Table 9.

Table 9: Respondents Reasons for Choosing Other Radio Station/Stations outside Cape Coast Metropolis

$$
\begin{aligned}
& \text { ADO PEAC ROCK ASEM JOY CITI MA SKY MELOD PARA MULT. } \\
& \begin{array}{lllllllll}
\text { MFM } & \text { EFM } & \text { FM } & \text { PAFM FM } & \text { FM } & X & \text { FM } & \text { Y FM } & \text { GON RESPO }
\end{array}
\end{aligned}
$$

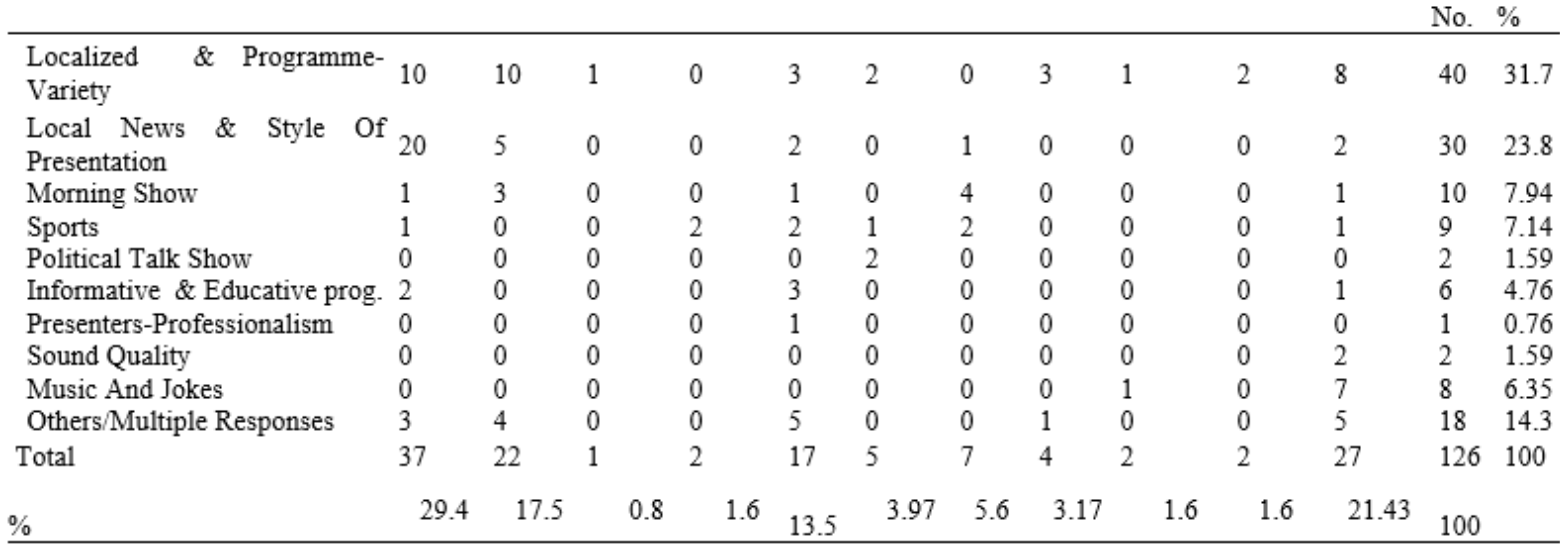

Page /9

Field Data, (2016)

From Table 9, it is clear that the number one radio station outside CCM patronized by respondents was Adom Fm (29.4\% ) followed by Peace Fm (17.5\%) and Joy Fm (13.5\%) all in Greater Accra. Reasons for listening to these other stations were basically localized \& variety of programmes (31.7\%); local news and style of presentation (23.8\%) and morning show (7.4\%). The first two radio stations rated higher outside CCM were Akan radio Station. This means that though the respondents were literate, they had the need for some programmes in the Akan language other than English.

This result corroborates that of IPSOS (Synovate) (2014). IPSOS (Synovate) found that the most listened radio station in Greater Accra was Adom Fm. However, this finding equally disagrees with Kwakwa (2012), who found that Joy FM was the most listened radio station in Accra. The finding further disagrees with that of GeoPoll (2015), who also disclosed that Peace Fm was the number one radio station in Accra. 
Table 10: Overall satisfaction with number one radio station from outside cape coast

\begin{tabular}{|l|c|c|c|c|}
\hline & EXCELLENT & VERY GOOD & GOOD & Total \\
\hline Adom Fm & 17 & 16 & 7 & 40 \\
\hline Others/Multiple Response & 12 & 11 & 4 & 27 \\
\hline Peace Fm & 16 & 5 & 4 & 25 \\
\hline Joy Fm & 5 & 8 & 3 & 16 \\
\hline Max Fm & 5 & 4 & 0 & 9 \\
\hline Citi Fm & 4 & 1 & 0 & 5 \\
\hline Sky Fm & 1 & 4 & 0 & 5 \\
\hline Asempa Fm & 0 & 2 & 0 & 2 \\
\hline Melody Fm & 0 & 2 & 0 & 2 \\
\hline Paragon Fm & 0 & 2 & 0 & 2 \\
\hline Rock Fm & 1 & 0 & 0 & 1 \\
\hline Total & 61 & 55 & 18 & 134 \\
\hline Page/9 & & &
\end{tabular}

Page $/ 9$

Field Data, (2016)

Majority of the respondents' overall satisfaction with radio stations outside CCM was excellent as indicated in Table 10. This means that radio stations outside CCM were performing better to listeners' expectations as compared to those found within CCM. However, with Sky FM, and Asempa FM, majority of the respondents indicated that their overall satisfaction level was very good but not excellent.

\section{Conclusion and recommendations}

The first research question of the study was on what caliber of people listened to radio in Cape Coast Metropolis? It can be concluded that the majority of listeners of radio in CCM were 20-25 years, males, government employees and first-degree holders. The second research question also sought to assess how demographic variables of respondents affect the predetermined factors on their choice of radio in CCM. It can also be concluded that radio station's image, presenters, status as a worker, commercial run and influence of others were perceived higher by respondents within the age bracket of 31- 35 than other age groups. Respondents in the age bracket of 36-40 also perceived News coverage and type of programme higher.

Finally religious beliefs and political orientation were perceived higher by respondents in the age bracket of 41 and above. Five significant factors identified in terms of effect of age on respondents' perception of the factors of the study were news coverage, status of respondents as workers, commercial run; religious beliefs and political orientation. It was also found that there was no statistically significant difference between employment status and all the nine factors of study. However, there was a statistical significance difference between educational level and five factors of the study such as Station's Image; news coverage; type of programmes; station presenters; and status as a worker.

The last research questions also sought to find out what programmes and timing make the best radio station in the CCM to respondents and can be concluded that the best three radio stations in CCM were Atlantic Fm, Cape Fm and Eagle Fm. The major programme of interest to listeners of radio in CCM was morning show. Respondents in CCM listened to radio more in the morning and evening (before work and after work) as compared to during working hours. Level of satisfaction for radio in CCM by respondents was very good but not excellent and for that reason listeners listened to other radio stations out of CCM largely from Accra, and respondents' level of satisfaction for these stations outside CCM was rather excellent.

The conclusion calls for action by the management of radio stations in CCM and the study, therefore, recommend that management of radio stations in CCM should:

1. Continue to partner with radio stations in the capital for broadcasting their major news

2. Introduce more educative programmes after morning show to retain their listeners during the afternoon or during working hours

3. Empanel competent and knowledgeable guest on their talk shows and morning shows

4. Train their presenters to be more professionals and competent.

5. Introduce new and interesting programmes to capture and retain listeners within the age bracket of 41 and above.

\section{REFERENCES}

Alumuku, P. (2006). Community radio for development: The world and Africa. Nairobi: Paulines.

Annor-Antwi, G. (2009). Listenership of Selected FM Stations: A Study of Koforidua Residents (Unpublished

Master's thesis). University of Ghana, Legon

Anquandah, J. (2012). Radio listening habits of New Abirem mining community residents. M.A Thesis, University 
Of Ghana, Legon. Retrieved from https://www.google.com.gh/?gfe_rd=cr\&ei=4Qhr wpndbenv8afulrywdw\&gwsrd

Bittner, John R. (1996). Mass Communication (6th Ed.). Boston: Allyn and Bacon.

Boateng, K. (2009). Radio in Accra: Communicating among linguistically and ethnically diverse audiences. International Communication Studies, Xviii,1-200

Bormann, B. K. (2015). Radio listening habits at the workplace: A study of Agona Swedru business community . Mphil Thesis, University of Education, Winneba

Chioma P. E., Solo-Anaeto, M., \& Jegede O. O. (2015). An evaluation of radio audience satisfaction with programming on inspiration $92.3 \mathrm{fm}$, Lagos. International Journal of Research in Humanities and Social Studies 2, (12), 99-106.

Gathigi, G. W. (2009). Radio Listening Habits among Rural Audiences: An Ethnographic Study of Kieni West Division in Central Kenya. Doctorial Thesis, Scripps College of Communication of Ohio University. Retrieved from rd=cr\&ei=KgxrWJOtL6T38AeYwp3QCg\&gws_rd=ssl\#q=Radio+Listening+

Ghana Statistical Service (2013). 2010 population and housing census: Regional analytical report for Greater Accra Region: Accra: Ghana Statistical Service

GeoPoll (2015). Radio Ratings in Ghana, May-July 2015. Retrieved from https://www.google com.gh/? gfe rd=cr\&ei=ShprWJH6A- v8AeWzZ3gDg\&gws_rd=ssl\#q

Katz, E., Gurevitch, M. \& Haas, H. (1973). On the use of the mass media for important things. American Sociological Review, 38

Kwakwa, P. A. (2012). Individual preference for radio stations in the Eastern Region of Ghana. Online Journal of Communication and Media Technologies, 2: 4- 8

Ocran, B. (2015). Assessing the effects of branding on radio listenership in Ghana. Case study of selected radio stations in Kumasi. MBA Thesis, Kwame Nkrumah University of Science and Technology (KNUST)

Ofori-Boateng, S.(1997). Phone-in Talk Radio Programmes: The Views of Students of the University of Ghana. (Unpublished Master's thesis). University of Ghana, Legon

McQuail, D., Blumler, J.G., \& Brown, J.R. (1972). The television audience: A revised perspective. In D. McQuail, ed., Sociology of Mass Communications Harmondsworth, Eng.: Penguin.

Melkote S \& Steeves, L. (2002) Communication for development in the Third World:Theory and Practice. New Delhi: Sage Publishers.

National Communications Authority (2016). List Of Authorised Vhf - Fm Radio Stations In Ghana. Third Quarter, 2016. Retrieved from www.ncu.ghana.

Wilson, E.J. III, (2000) 'Closing the digital divide: an initial review', Internet Policy Institute, July. Online. Available: www.Internetpolicy.org.

United Nations Education Scientific and Cultural Organization (1961). Manual on adult and youth education. Paris: UNESCO. 